\title{
Cefuroxime, a New Cephalosporin Antibiotic: Activity In Vivo
}

\author{
D. M. RYAN, CYNTHIA H. O’CALLAGHAN, AND P. W. MUGGLETON* \\ Glaxo Research Ltd., Greenford, Middlesex, England
}

Received for publication 25 September 1975

\begin{abstract}
The pharmacokinetic properties of cefuroxime have been evaluated in laboratory animals. On injection into mice, rats, and rabbits by the subcutaneous or intramuscular routes, high serum level peaks were recorded. There was no significant absorption after oral administration. After injection, the antibiotic was excreted in large amounts in the urine. It was well distributed in the body and penetrated into the tissues at a satisfactory rate. This, coupled with a low degree of serum protein binding, was correlated with a very good protective effect in animals (mice, rats, and rabbits) experimentally infected with a wide range of bacteria, including $\beta$-lactamase-producing strains. It is concluded that cefuroxime should have a good potential for treating a wide range of bacterial infections in humans.
\end{abstract}

It has been shown (2) that cefuroxime, a new antibiotic of the cephalosporin series, has good activity in vitro against a wide range of bacterial species, including many strains which, being producers of $\beta$-lactamase, are resistant to many of the existing cephalosporins and penicillins.

Following the in vitro work, an evaluation of the pharmacokinetic properties of the compound and of its ability to protect against a range of bacterial infections in various animal species was undertaken. The results are reported here.

\section{MATERIALS AND METHODS}

Cefuroxime, cephalexin, cephalothin (sodium salts), and cephaloridine were prepared in our own laboratories as pure crystalline materials. Cefazolin (Totacef intramuscular, Bristol Laboratories Inc.) was obtained commercially. The materials were all administered as solutions in physiological saline solution. In the case of the cephalosporins, which were used as sodium salts, dosages were calculated to refer to the amount of free acid present.

The animals used were albino, Charles River female mice, weighing 18 to $20 \mathrm{~g}$, albino female rats, Wistar strain, weighing $100 \mathrm{~g}$, and Californian rabbits, weighing 2.0 to $2.5 \mathrm{~kg}$. Antibiotic injections were made in $0.2-\mathrm{ml}$ volumes in mice and rats and in volumes of $0.25 \mathrm{ml} / \mathrm{kg}$ in rabbits.

Cefuroxime concentrations in tissues and body fluids. Cefuroxime, at various dose levels, was administered to mice, rats, or rabbits and, at different intervals of time thereafter, samples of serum, lung, liver, spleen, and kidney were obtained and assayed for their cefuroxime content. Urine samples were collected from animals kept in metabolism cages arranged for the collection of urine at periods of 0 to $6 \mathrm{~h}$ and 6 to $24 \mathrm{~h}$ after giving the dose of antibiotic. Serum and urine from individual rats and rabbits were collected and assayed. Pooled samples of serum, urine, and tissues from groups of three mice were used.

Interstitial fluid was collected from silicone baskets subcutaneously implanted in the neck region (1). The baskets were made from translucent silicone rubber tubing (internal diameter, $13 \mathrm{~mm}$, and wall thickness, $5 \mathrm{~mm}$ ) (Esco Rubber Ltd., London). The open ends of the cylinders were plugged with a roll of silicone rubber, $5 \mathrm{~mm}$ wide, giving a closed cylinder with an external length of $50 \mathrm{~mm}$ and an internal length of $40 \mathrm{~mm}$. Each cylinder was converted into a basket by punching 42 holes (5 $\mathrm{mm}$ in diameter) in the walls, leaving a central nonperforated region that was $10 \mathrm{~mm}$ wide. The area represented by the holes was $43 \%$ of the total internal surface area. The baskets had been implanted, four per rabbit, for 12 months prior to the experiment reported here; each contained clear, pale-colored fluid. At various times after the intramuscular injection of cefuroxime, 0.5 $\mathrm{ml}$ of fluid from the basket was aspirated and blood was collected from a marginal ear vein. The position of each basket was noted and they were sampled in rotation. It was found that, in any one animal, concentrations of antibiotic showed small variation from one basket to another.

Peritoneal, pleural, and pericardial fluids were removed from rabbits killed at various times after intramuscular injection with cefuroxime.

Cefuroxime assay. Concentrations of cefuroxime in serum, tissue homogenates, and body fluids were determined by microbiological assay. The medium was prepared by dissolving $5 \mathrm{~g}$ of Oxoid peptone, $3 \mathrm{~g}$ of Oxoid Lab Lemco, $10 \mathrm{~g}$ of sodium citrate, $5 \mathrm{~g}$ of sodium chloride, and $12 \mathrm{~g}$ of agar (Difco) in distilled water to give 1 liter at pH 7.0 
and was seeded with Bacillus subtilis NCIB 8993. Standards $(1.25,0.625,0.312$ and $0.15 \mu \mathrm{g} / \mathrm{ml})$ and samples were plated in a random design into holes punched in the agar so that each appeared four times on the plate. Standard solutions were prepared in pH 7.0 0.05 M phosphate buffer. Sera and urines were diluted in the same buffer. Provided the serum samples were diluted at least 1:4, no interference with the assay was observed from the presence of serum protein.

Because of the small volumes of peritoneal, pericardial, and pleural fluids available, these were assayed by applying $25-\mu \mathrm{l}$ volumes to Whatman AA disks $(6 \mathrm{~mm})$ by means of microcapillary pipettes. Four disks were used for each sample of fluid. Disks were prepared with standard concentrations of cefuroxime. The disks were applied to the same assay medium as used in the well-plate assay, seeded, and read as outlined above.

Experimental chemotherapy. Protection tests were done on mice and rats experimentally infected with a range of microorganisms. At the time that the tests were done, the challenge strains were tested for sensitivity to the various antibiotics by an agar plate dilution method (2). Mice were challenged by the intraperitoneal route with the test organisms suspended in $0.2 \mathrm{ml}$ of $4 \%$ hog gastric mucin. Rats were challenged by the same route in $a$ $2 \%$ suspension of killed, dried brewers' yeast. The challenge dose in both species was approximately 10 to 100 times the mean lethal dose, and the majority of untreated animals died within $24 \mathrm{~h}$ of challenge. Five to eight animals were used at each of the serial threefold dose concentrations of antibiotic tested, which were given subcutaneously $(0.2 \mathrm{ml} /$ animal) at 1 and $5 \mathrm{~h}$ after challenge. The number of animals surviving on day 5 was used to calculate the median effective dose by logit transformation of the dose response curve.

Californian rabbits (2.0 to $2.5 \mathrm{~kg}$ ) were challenged intravenously with a suspension of Staphylococcus aureus $630(0.5 \mathrm{ml} / \mathrm{kg}$ of body weight). The challenge dose was such that approximately $50 \%$ of the untreated controls died between 24 and $28 \mathrm{~h}$, and all died within $48 \mathrm{~h}$. Five animals were used at each of the serial twofold concentrations of antibiotic, which were given intramuscularly at 1 and 5 $h$ postchallenge. The number of survivors on day 5 was counted, and the median effective dose was calculated by logit transformation of the dose response curve.

\section{RESULTS}

Serum levels and urinary excretion. The serum antibiotic levels and urinary recoveries after subcutaneous or intramuscular injection of cefuroxime in single doses to mice, rats, rabbits, and dogs are shown in Table 1 . Absorption of the antibiotic was rapid from the injection site, and peak serum levels were recorded at $15 \mathrm{~min}$ after injection. Elimination from the serum tended to be rapid in the smaller rodents (rats and mice), and the duration of the serum levels became more prolonged in rabbits and dogs when the size of the dose was increased. Urinary recovery values also increased in proportion to the size of the animal and in rabbits and dogs approached the values found in humans (R. D. Foord, submitted for publication). Cefuroxime gave good serum levels at feasible doses of antibiotic, the levels being sufficient to cover the mini-

TABLE 1. Serum levels and percentage of urinary recoveries of cefuroxime in mice, rats, rabbits, or dogs after subcutaneous or intramuscular administration in single doses

\begin{tabular}{|c|c|c|c|c|c|c|c|c|c|}
\hline \multirow{2}{*}{ Species } & \multirow{2}{*}{ Route } & \multirow{2}{*}{$\begin{array}{c}\text { Dose } \\
(\mathbf{m g} / \mathbf{k g})\end{array}$} & \multirow{2}{*}{$\begin{array}{c}\text { No. of } \\
\text { animals }\end{array}$} & \multicolumn{5}{|c|}{ Average serum concentrations at $(h)$ : } & \multirow{2}{*}{$\begin{array}{c}\text { Overall } \\
\text { average } \\
\% \text { uri- } \\
\text { nary re- } \\
\text { covery }\end{array}$} \\
\hline & & & & 0.25 & 0.5 & 1 & 2 & 4 & \\
\hline \multirow[t]{3}{*}{ Mouse } & Subcutaneous & 25 & $7^{a}$ & 19.5 & 13.7 & 3.9 & $<1$ & $<1$ & 33 \\
\hline & Subcutaneous & 50 & $8^{a}$ & 50 & 33 & 8.1 & $<1$ & $<1$ & 50 \\
\hline & Subcutaneous & 100 & $5^{a}$ & 61 & 53 & 12.1 & $<1$ & $<1$ & 31 \\
\hline \multirow[t]{4}{*}{ Rat } & Subcutaneous & 25 & 5 & 21 & 13.5 & 4.8 & 1.4 & $<1$ & 52 \\
\hline & Subcutaneous & 50 & 13 & 50 & 41 & 19.2 & $<1$ & $<1$ & 51 \\
\hline & Subcutaneous & 100 & 5 & 89 & 64 & 38 & 9.8 & 2.4 & 67 \\
\hline & Subcutaneous & 500 & 4 & 345 & 339 & 236 & 71 & 3.9 & 50 \\
\hline \multirow[t]{3}{*}{ Rabbit } & Intramuscular & 25 & 5 & 32 & 21 & 7.1 & $<1$ & $<1$ & 81 \\
\hline & Intramuscular & 50 & 5 & 84 & 61 & 21 & $<6$ & $<1$ & 75 \\
\hline & Intramuscular & 100 & 10 & 192 & 96 & 51 & 16.5 & $<2$ & 100 \\
\hline \multirow[t]{3}{*}{ Dog } & Intramuscular & 60 & 4 & $\mathrm{NT}^{b}$ & 70 & 56 & 32 & 6 & 66 \\
\hline & Intramuscular & 180 & 4 & NT & 200 & 154 & 103 & 22 & 70 \\
\hline & Intramuscular & 540 & 4 & NT & 835 & 853 & 320 & 73 & 69 \\
\hline
\end{tabular}

\footnotetext{
${ }^{a}$ Each sample was a pool from six mice.
}

${ }^{b}$ NT, Not tested. 
mum inhibitory concentrations against many susceptible strains of bacteria. In all cases the injections were well tolerated, and the animals showed no signs of malaise after the injections.

Urine samples from representative animals were investigated by chromatography (70\% propanol-30\% water; Whatman no. 1 paper buffered to $\mathrm{pH} 7.0$ with phosphate buffer) followed by bioautographs on nutrient agar (using the Oxford strain of $S$. aureus). No spot corresponding to the 3-hydroxymethyl analogue was seen, indicating that the esterified carbamate group at position 3 in cefuroxime is stable in the animal body.

In mice, rats, and rabbits to which cefuroxime was given orally at $100 \mathrm{mg} / \mathrm{kg}$, only very low serum levels and urinary recoveries of 1 to $3 \%$ were recorded. It was concluded that the antibiotic is not significantly absorbed from the gastrointestinal tract.

The effect of giving probenecid along with the cefuroxime was tested on mice and rats. Serum levels and urinary recoveries were measured in both species after giving, by subcutaneous injection, cefuroxime at $50 \mathrm{mg} / \mathrm{kg}$ with and without probenecid. The probenecid, at $500 \mathrm{mg} / \mathrm{kg}$, was given orally $30 \mathrm{~min}$ before giving the injection of cefuroxime. The results indicate that probenecid has only a marginal effect on the size and duration of blood levels in these species and it does not affect the overall urinary recovery of the antibiotic (Table 2). It was concluded that tubular secretion must account for only a small part of the excretion of cefuroxime in these species and that most is likely to be eliminated by glomerular filtration.

Tissue levels. Cefuroxime levels in the serum, kidney, liver, spleen, and lung after giving single injections of $100 \mathrm{mg} / \mathrm{kg}$ are shown in Table 3. The antibiotic was given subcutaneously in rats and mice and intramuscularly in rabbits. The tissues were sampled at
0.5 and $1 \mathrm{~h}$ after giving the cefuroxime. The solid tissues were assayed by preparing 1:4 homogenates in physiological saline in a blender. The results showed a typical distribution pattern for a cephalosporin antibiotichigher levels in the kidney, reflecting the excretion of the antibiotic by that organ. Although there were signs of concentration of the antibiotic in the liver in rats, this was not seen in rabbits. This, together with the observed high urinary recovery in the rabbit (Table 1), suggests that excretion of cefuroxime by the liver is minimal in that species. Lung and spleen levels were lower than the serum levels at the corresponding time, a not unexpected finding after a single dose of the antibiotic.

Average cefuroxime levels in the serum, peritoneal fluid, pleural fluid, and pericardial fluid of rabbits after a single dose of $50 \mathrm{mg} / \mathrm{kg}$ intramuscularly to rabbits are shown in Fig. 1. The serum levels were higher than those in the serous fluids, although therapeutic levels were reached in all of them, especially in the peritoneal fluid. There was a suggestion that the serous fluid levels might be more persistent.

Figure 2 shows the average cefuroxime levels in the serum of rabbits given a single dose of $50 \mathrm{mg} / \mathrm{kg}$ intramuscularly. At the same times, interstitial fluid from subcutaneously implanted plastic baskets was assayed, and the results are also illustrated in Fig. 2. The persistence of the tissue fluid levels as compared with the serum levels is clearly shown in this experiment, and it led to the belief that a "staircase effect" might be obtained on repeated dosing. An interval of $3 \mathrm{~h}$ between the repeated injections was chosen since cefuroxime is essentially excreted from the serum in rabbits at this time. The results of giving 10 repeated doses of $50 \mathrm{mg} / \mathrm{kg}$ at $3-\mathrm{h}$ intervals is shown in Fig. 3. At each sampling, the serum and interstitial fluid were withdrawn immediately before giving the next 3 -h dose.

TABLE 2. Effect of probenecid (500 $\mathrm{mg} / \mathrm{kg}$, orally) on serum levels and urinary excretion of cefuroxime given subcutaneously at $50 \mathrm{mg} / \mathrm{kg}$ to rats and mice

\begin{tabular}{|c|c|c|c|c|c|c|c|c|}
\hline \multirow{2}{*}{ Species } & \multirow{2}{*}{$\begin{array}{l}\text { With/without probe- } \\
\text { necid }^{a}\end{array}$} & \multicolumn{6}{|c|}{ Serum levels $(\mu \mathrm{g} / \mathrm{ml})$ at $(\mathrm{h})$ : } & \multirow{2}{*}{$\begin{array}{c}\text { Overall \% } \\
\text { urinary re- } \\
\text { covery }\end{array}$} \\
\hline & & 0.25 & 0.5 & 1 & 2 & 3 & 4 & \\
\hline Mouse $^{b}$ & $\begin{array}{l}\text { With } \\
\text { Without }\end{array}$ & $\begin{array}{l}59 \\
31\end{array}$ & $\begin{array}{l}40 \\
30\end{array}$ & $\begin{array}{r}20 \\
9\end{array}$ & $\begin{array}{l}3.8 \\
1.1\end{array}$ & $\begin{array}{l}1.3 \\
1.0\end{array}$ & $\begin{array}{l}\text { NTr } \\
\text { NT }\end{array}$ & $\begin{array}{l}35 \\
32\end{array}$ \\
\hline $\mathbf{R a t}^{d}$ & $\begin{array}{l}\text { With } \\
\text { Without }\end{array}$ & $\begin{array}{l}70 \\
40\end{array}$ & $\begin{array}{l}59 \\
36\end{array}$ & $\begin{array}{l}22 \\
18.9\end{array}$ & $\begin{array}{l}1 \\
5.7\end{array}$ & $\begin{array}{l}\text { NT } \\
\text { NT }\end{array}$ & $\begin{array}{l}<1 \\
<1\end{array}$ & $\begin{array}{l}43 \\
44\end{array}$ \\
\hline
\end{tabular}

a Probenecid given 30 min before the cefuroxime.

bach serum sample represents a pool from three mice.

c NT, Not tested.

${ }^{d}$ Each value is the average from four rats; the sera were assayed separately. 
TABLE 3. Cefuroxime concentrations in serum and tissues of laboratory animals after single injections of $100 \mathrm{mg} / \mathrm{kg}$

\begin{tabular}{llcc}
\hline \multirow{2}{*}{ Species } & Tissue & \multicolumn{2}{c}{$\begin{array}{c}\text { Serum or tissue level }(\mu \mathrm{g} / \\
\text { ml or } \mu \mathrm{g} / \mathrm{g}) \text { at }(\mathbf{h}):\end{array}$} \\
\cline { 2 - 4 } & & $0.5^{a}$ & $1^{a}$ \\
\hline Mouse. & Serum & 53 & 12 \\
& Kidney & 155 & 23 \\
& Liver & 55 & 16.8 \\
& Spleen & $<6$ & $<5$ \\
& Lung & 17.6 & $<5$ \\
Rat & & & \\
& Serum & 76 & 49 \\
& Kidney & 158 & 60 \\
& Liver & 134 & 49 \\
& Spleen & 13.6 & $<5$ \\
& Lung & 43 & 13.7 \\
Rabbit & & & \\
& Serum & 81 & 51 \\
& Kidney & 833 & 295 \\
& Liver & 25 & $<10$ \\
& Spleen & 10 & 29 \\
& Lung & 38 & 14.9 \\
\hline
\end{tabular}

a Average from five samples at each time. Samples were from individual rats and rabbits and pools were from six mice.

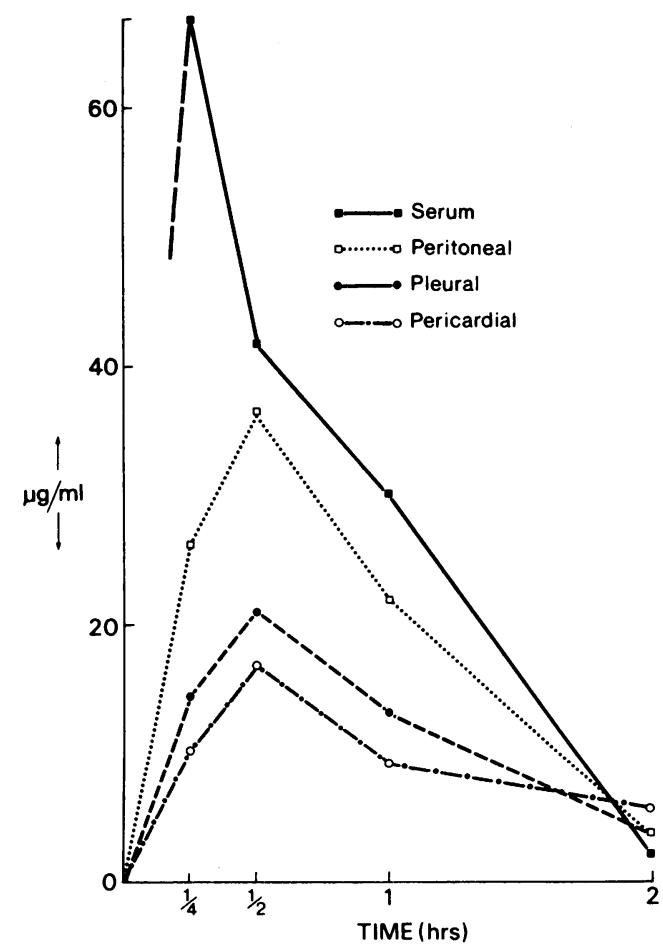

Fig. 1. Cefuroxime levels in serum and in peritoneal, pleural, and pericardial fluids after a single dose of $50 \mathrm{mg} / \mathrm{kg}$ intramuscularly in rabbits.
The serum levels climbed very slowly, this being consistent with a very small "overlap" in the serum levels (cf. Fig. 2). The more persistent interstitial fluid levels, however,

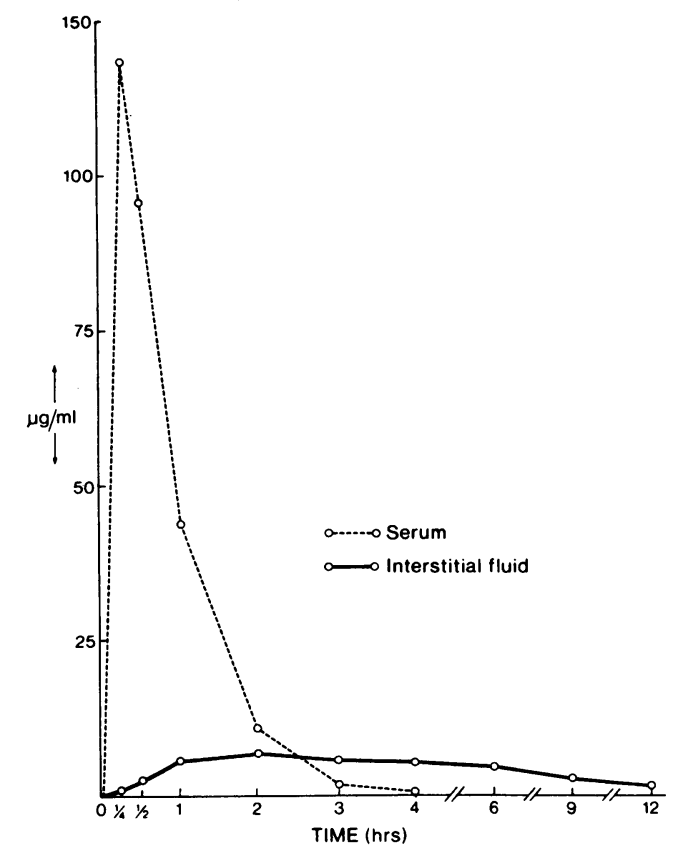

Fig. 2. Cefuroxime levels in serum and interstitial fluid (from subcutaneous basket implants) after a single dose of $50 \mathrm{mg} / \mathrm{kg}$ intramuscularly in rabbits.

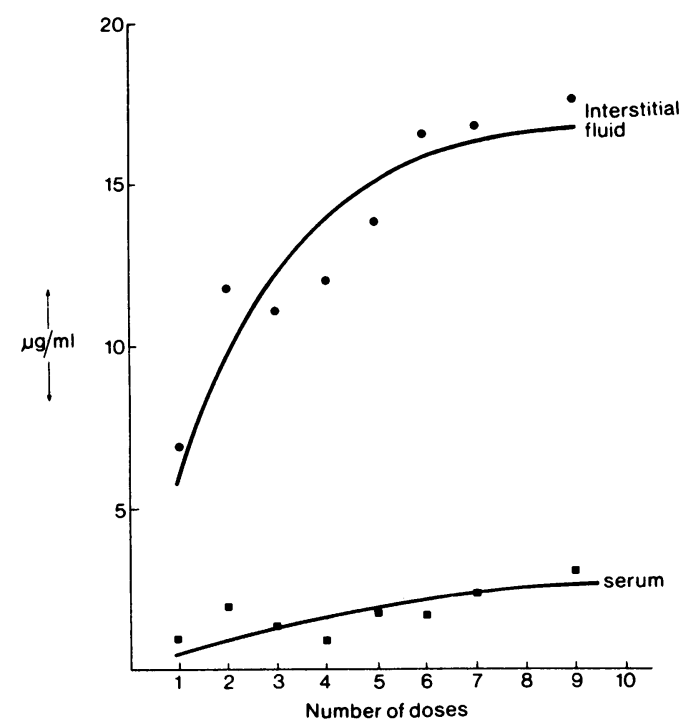

Fig. 3. Cefuroxime levels in serum and interstitial fluid after multiple $3-\mathrm{h}$ doses of $50 \mathrm{mg} / \mathrm{kg}$ intramuscularly in rabbits. The samples were withdrawn at $3 h$ after each injection, just before the next dose was given. 
climbed to a plateau of some $17 \mu \mathrm{g} / \mathrm{ml}$ after giving six doses.

Protection tests. Minimum inhibitory concentrations in vitro of cefuroxime, cephalexin, cefazolin, cephaloridine, and cephalothin against the test organisms used in the protection tests are shown in Table 4. The $\beta$-lactamase-producing strains of Proteus spp., Enterobacter cloacae, and Klebsiella aerogenes can readily be identified by the lack of activity on the part of the $\beta$-lactamase-susceptible cephalosporins. The greater activity of the $\beta$-lactamase-stable cefuroxime is evident.

Table 5 summarizes the results of protection tests on mice and rats challenged with a range of test organisms and treated with cefu- roxime, cephalexin, cefazolin, cephaloridine, and cephalothin. Cefuroxime was effective in protecting against all of the test organisms used, in most cases at low dose levels. The activities of the other cephalosporins were usually related to the sensitivities of the strains in vitro (Table 4), although some exceptions were recorded. These exceptions can probably be accounted for by the fact that some test organisms probably produce smaller amounts of $\beta$-lactamase. Moreover, in this kind of test, some of the cephalosporins with a very rapid antibacterial activity, e.g., cephaloridine, may protect the animals by killing the challenge organisms before their $\beta$-lactamase has had time to work. Good protection

TABLE 4. Activity of cefuroxime and other cephalosporins against bacterial species used in protection tests

\begin{tabular}{lccccc}
\hline \multirow{2}{*}{ Organism $^{a}$} & \multicolumn{5}{c}{ Minimum inhibitory concentration $(\mu \mathrm{g} / \mathrm{ml})$} \\
\cline { 2 - 6 } & Cephalexin & Cefazolin & Cephaloridine & Cephalothin & Cefuroxime \\
\hline Staphylococcus aureus 853 & 1 & 0.25 & 0.5 & 0.25 & 1 \\
S. aureus 630 & 1 & 1 & 8 & 0.5 & 0.5 \\
Escherichia coli 851 & 8 & 1 & 4 & 8 & 4 \\
E. coli 573 & 16 & 1 & 4 & 8 & 4 \\
Proteus mirabilis 431 & 16 & 31 & 31 & 31 & 4 \\
P. morganii 1375 & $>250$ & $>250$ & $>250$ & $>250$ & 4.5 \\
P. morganii 235 & $>250$ & 125 & $>250$ & 250 & 4 \\
P. morganii Rooney & $>250$ & 125 & $>250$ & 250 & 4 \\
P. vulgaris 52740 & $>250$ & 250 & $>250$ & $>250$ & 16 \\
Enterobacter cloacae 817501 & $>250$ & 250 & $>250$ & $>250$ & 16 \\
Klebsiella aerogenes 46189 & 31 & 62.5 & 250 & 125 & 31 \\
\hline
\end{tabular}

${ }^{a}$ Initial inoculum level was $10^{7}$.

TABLE 5. Protection tests on experimentally infected mice and rats

\begin{tabular}{|c|c|c|c|c|c|c|}
\hline \multirow[b]{2}{*}{ Species } & \multirow[b]{2}{*}{ Challenge organism and strain } & \multicolumn{5}{|c|}{ Median effective dose in $\mathbf{m g} / \mathbf{k g}$ per dose of: } \\
\hline & & Cephalexin & Cefazolin & $\begin{array}{l}\text { Cephalori- } \\
\text { dine }\end{array}$ & Cephalothin & Cefuroxime \\
\hline Mouse & $\begin{array}{l}\text { Staphylococcus aureus } 853 \\
\text { S. aureus } 630 \\
\text { Escherichia coli } 573 \\
\text { E. coli } 851 \\
\text { Proteus mirabilis } 431 \\
\text { P. morganii (Rooney) } \\
\text { P. morganii } 1375 \\
\text { P. vulgaris } 52740 \\
\text { Enterobacter cloacae } 817501 \\
\text { Klebsiella aerogenes } 46189\end{array}$ & $\begin{array}{r}4 \\
44 \\
13 \\
2 \\
25 \\
9 \\
\mathrm{NT}^{a} \\
>200 \\
57 \\
25\end{array}$ & $\begin{array}{r}3 \\
8 \\
6 \\
1 \\
19 \\
19 \\
133 \\
182 \\
43 \\
6\end{array}$ & $\begin{array}{r}<0.8 \\
2 \\
8 \\
4 \\
5 \\
25 \\
133 \\
>200 \\
77 \\
15\end{array}$ & $\begin{array}{r}8 \\
33 \\
70 \\
>50 \\
6 \\
19 \\
20 \\
>200 \\
106 \\
>200\end{array}$ & $\begin{array}{r}5 \\
2 \\
4 \\
5 \\
2 \\
2 \\
8 \\
35 \\
6 \\
6\end{array}$ \\
\hline Rat & $\begin{array}{l}\text { Staphylococcus aureus } 853 \\
\text { S. aureus } 630 \\
\text { Escherichia coli } 851 \\
\text { Proteus mirabilis } 431 \\
\text { P. morganii } 235 \\
\text { P. morganii } 1375 \\
P \text {. vulgaris } 52740 \\
\text { Enterobacter cloacae } 817501 \\
\text { Klebsiella aerogenes } 46189\end{array}$ & $\begin{array}{r}9 \\
5 \\
23 \\
16 \\
138 \\
>150 \\
\text { Ca. } 150 \\
25 \\
\mathrm{NT}\end{array}$ & $\begin{array}{r}3 \\
1 \\
10 \\
40 \\
131 \\
>150 \\
>150 \\
>150 \\
30\end{array}$ & $\begin{array}{r}<2 \\
1 \\
10 \\
40 \\
131 \\
>150 \\
\text { Ca. } 150 \\
>150 \\
45\end{array}$ & $\begin{array}{r}6 \\
4 \\
59 \\
84 \\
>150 \\
>150 \\
>150 \\
>150 \\
>150\end{array}$ & $\begin{array}{r}5 \\
1 \\
32 \\
26 \\
5 \\
29 \\
55 \\
7 \\
8\end{array}$ \\
\hline
\end{tabular}

a NT, Not tested. 
with cefuroxime was seen in both mice and rats and should be considered in relation to the relatively short duration of serum levels produced in these species (Table 1) by the administration of the modest dose levels required for protection.

The results of a protection test on rabbits challenged intravenously with $S$. aureus strain 630 (a penicillinase-producing strain) are shown in Table 6. Cefuroxime, cephalexin, cefazolin, and cephaloridine were compared in this test. All of the compounds tested gave satisfactory protection, but cephaloridine was the most effective, a reflection of the very rapid lytic action of that substance.

\section{DISCUSSION}

Cefuroxime, a new cephalosporin antibiotic with resistance to destruction by most $\beta$-lactamases, shows a favorable pharmacokinetic pattern in experimental animals. High serum levels result from single subcutaneous or intramuscular injections, although the substance is not absorbed when given by mouth. The antibiotic is eliminated quite rapidly in small rodents, but in larger animals it is more persistent. Excretion appears to be via the kidney and to take place mainly by glomerular filtration. The substance is stable in the animal body in that the carbamate group at position 3 is not removed by esterases. This is in contrast to 3-acetoxymethyl cephalosporins (e.g., cephalothin) in which de-esterification occurs rapidly in rodents.

TABLE 6. Protection test on rabbits challenged intravenously with $S$. aureus strain 630

\begin{tabular}{lc}
\hline Antibiotic & $\begin{array}{c}\text { Median effective dose }{ }^{a} \\
(\mathrm{mg} / \mathrm{kg} \text { per dose })\end{array}$ \\
\hline Cefuroxime & 3 \\
Cephalexin & 13 \\
Cefazolin & 1 \\
Cephaloridine & $<1$ \\
\hline
\end{tabular}

a Calculated from the numbers of survivors on postchallenge day 5 .
From the blood stream, cefuroxime penetrates readily into the tissues and serous fluids and, in rabbits, good persistence of the antibiotic was seen such that a buildup of antibiotic levels took place when repeated doses were given just before the serum levels fell to zero. In rabbits given $50 \mathrm{mg} / \mathrm{kg}$, this was at $3-\mathrm{h}$ intervals. Work on human volunteers (R.D. Foord, submitted for publication) has shown that the corresponding period in humans given smaller doses ( 7 to $15 \mathrm{mg} / \mathrm{kg}$ ) is about $8 \mathrm{~h}$, and it seems likely that tissue fluid levels would show a stepwise increase after repeated doses in humans also.

Protection tests in mice, rats, and rabbits against a wide range of pathogenic strains of bacteria showed that the antibiotic, which is not de-esterified in the body, is able to protect efficiently against such lethal infections. In particular, since many of the test strains used were $\beta$-lactamase-producing gram-negative bacilli, it was evident that cefuroxime was an effective antibiotic in vivo where other $\beta$-lactamase-susceptible cephalosporins were ineffective or less effective. It is concluded that the antibiotic is likely to be successful in treating a wide range of infections in humans.

Toxicity tests, which will be reported elsewhere, showed that the substance is of low toxicity and, in particular, does not have any toxic action on the kidney or liver. The way is, therefore, opened for the evaluation of cefuroxime in humans.

\section{ACKNOWLEDGMENTS}

We thank W. B. Barber and D. Monsey for technical help in the work described in this paper.

\section{LITERATURE CITED}

1. Calnan, J. S., P. M. Ford, P. J. L. Holt, and J. J. Pflug. 1972. Implanted tissue cages-a study in rabbits. Br. J. Plast. Surg. 25:164-174.

2. O'Callaghan, C. H., R. B. Sykes, A. Griffiths, and J. E. Thornton. 1976. Cefuroxime, a new cephalosporin antibiotic: activity in vitro. Antimicrob. Agents Chemother. 9:511-519. 